Check for updates

Cite this: RSC Adv., 2018, 8, 31106

Received 22nd June 2018

Accepted 18th August 2018

DOI: $10.1039 / \mathrm{c} 8 \mathrm{ra05359f}$

rsc.li/rsc-advances

\section{Al(III)-responsive "off-on" chemosensor based on rhodamine derivative and its application in cell imaging $\uparrow$}

\begin{abstract}
Chunwei Yu, ${ }^{\mathrm{a}} \mathrm{Li}$ Jian, ${ }^{\star a}$ Yuxiang $\mathrm{Ji}^{\mathrm{a}}$ and Jun Zhang (D) *ab
In this work, a new rhodamine chemosensor $(\mathrm{P})$ with excellent photochromic properties upon vis irradiation was designed and synthesized. The fabricated chemosensor $\mathrm{P}$ could detect $\mathrm{Al}^{3+}$ via the opening of the spirolactam ring of the rhodamine unit with high selectivity and sensitivity. The spirolactam ring opening was confirmed by NMR and infrared spectroscopy. Upon binding with $\mathrm{Al}^{3+}$, the generated $1: 1 \mathrm{P}-\mathrm{Al}^{3+}$ complex, confirmed by Job's plot titrations and mass spectrometry analysis, could exhibit a remarkable fluorescence enhancement with a limit of detection (LOD) of $0.16 \mu \mathrm{M}$. Furthermore, the sensing of $\mathrm{P}$ to $\mathrm{Al}^{3+}$ in vivo was also studied quantitatively and qualitatively in detail, and the results showed that the coordination between $\mathrm{P}$ with $\mathrm{Al}^{3+}$ was reversible in living cells.
\end{abstract}

\section{Introduction}

As the most abundant ( $8.3 \%$ by weight) metallic element and the third most abundant of all elements (after oxygen and silicon), aluminum has been widely used in many industrial and domestic fields. ${ }^{1}$ Nowadays, because of acidic rain and human activities in the environment, increasing exposure to free aluminum ions $\left(\mathrm{Al}^{3+}\right)$ poses a severe threat to biospheres and human health. According to the WHO report, the average daily human intake of aluminium is approx. $3-10 \mathrm{mg} \mathrm{d}^{-1}$, and the tolerable weekly aluminium intake in the human body is estimated to be $7 \mathrm{mg} \mathrm{kg}{ }^{-1}$ body weight. ${ }^{2}$ Excessive aluminum not only hampers plant and animals, but also damages the central nervous system to cause human illnesses like Alzheimer's and Parkinson's diseases. ${ }^{3}$ In this regard, detection of $\mathrm{Al}^{3+}$ in living biosystems is of great importance, not only for monitoring aluminum contamination but also for understanding its biological functions.

Fluorescent chemosensors have been proven to be a useful tool for sensing biologically important species in vitro and/or in vivo because of their non-destructive character, instantaneous response, simplicity and high sensitivity. ${ }^{4}$ In particular, for a certain purpose, it is highly demanding to selectively sense metal ions. Nevertheless, compared to other metal ions, effective design of $\mathrm{Al}^{3+}$-specific fluorescent chemosensors has always been problematic due to the lack of spectroscopic

${ }^{a}$ Department of Environmental Sciences, School of Tropical and Laboratory Medicine, Hainan Medical University, Haikou 571199, P. R. China. E-mail:jianli0622@163.com ${ }^{b}$ School of International Education, Hainan Medical University, Haikou 571199, P. R. China. E-mail:jun_zh1979@163.com

$\dagger$ Electronic supplementary information (ESI) available: Experimental characterizations (PDF). See DOI: 10.1039/c8ra05359f characteristics and poor coordination ability. ${ }^{5}$ Recently, based on the photophysical processes, number of signal mechanisms like photo-induced electron transfer (PET), ${ }^{6}$ intramolecular charge transfer (ICT), ${ }^{7} \mathrm{C}=\mathrm{N}$ isomerization ${ }^{8}$ and fluorescence resonance energy transfer (FRET) have been emerged for the development of $\mathrm{Al}^{3+}$ fluorescent chemosensors. ${ }^{9}$ Unfortunately, their selectivity and sensitivity is limited due to the interference of other trivalent ions, such as $\mathrm{Fe}^{3+}$ and $\mathrm{Cr}^{3+},{ }^{\mathbf{1 0}}$ moreover, visible light excitable chemosensors, highly desirable for in vivo intracellular recognition and trace level determination of $\mathrm{Al}^{3+}$ are lacking too, ${ }^{\mathbf{1 1}}$ and sensing materials for $\mathrm{Al}^{3+}$ detection in aqueous media are also still rare. ${ }^{12}$ These limitations have severely prevented their further applications in environmental and biological systems.

Rhodamine derivatives possess excellent spectroscopic properties such as a large molar extinction coefficient, high fluorescence quantum yields, and visible light excitation as well as long wavelength emission, which is more optimal for visualizing subcellular distribution of analytes in physiological processes. Moreover, rhodamine derivatives are nonfluorescent and colorless, but ring-opening of the corresponding spirolactam via coordination with metal ions or irreversible chemical reactions gives rise to a strong fluorescence emission and a pink color. ${ }^{13}$ This response system has confirmed the great potential for environmental and biological studies in terms of selectivity and sensitivity. In the context of long-term interests in searching for fluorescent chemosensors for $\mathrm{Al}^{3+}$, rhodamine spirolactam-based chemosensors for "turn-on" detection of $\mathrm{Al}^{3+}$ have been designed. ${ }^{\mathbf{1 4}}$ Paul et al. designed a rhodamine-naphthalene conjugate for the ratiometric fluorescent detection of $\mathrm{Al}^{3+} \cdot{ }^{\mathbf{1 4 a}}$ In another example, the combination of rhodamine and C-dots units has been employed for the detection of $\mathrm{Al}^{3+} \cdot{ }^{\mathbf{1 4 b}}$ However, these reported rhodamine 

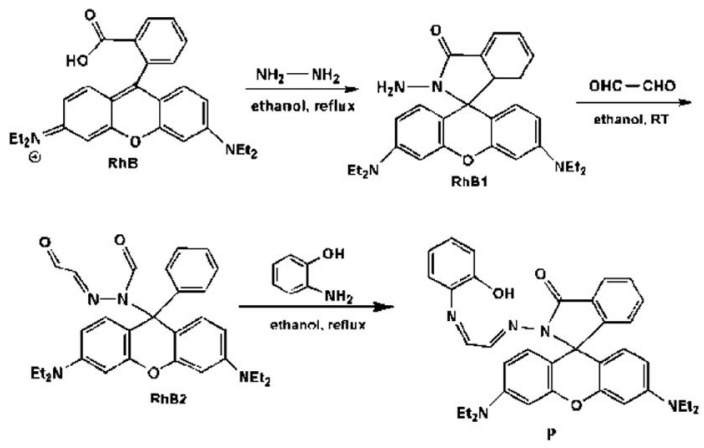

Scheme 1 Synthesis route of $\mathrm{P}$.

fluorogens usually work in pure organic or organic-aqueous solvents (with high content of organic reagents), resulting in the insufficient biocompatibility. ${ }^{14 c-e}$ Hence, novel rhodamine chemosensors with high selectivity and sensitivity is more desirable for $\mathrm{Al}^{3+}$ quantitation and bioimaging detection.

Additionally, based on our previous research, it is necessary to consider the geometry of coordination sites for a certain metal ion. Introduction of $\mathrm{O}$ and $\mathrm{N}$ donor atoms to the structure of compounds proved the coordination ability of the proposed chemosensors to $\mathrm{Al}^{3+} .{ }^{15}$ Herein, a new and simple $\mathrm{Al}^{3+}$-selective fluorescent chemosensor $\mathbf{P}$ based on rhodamine derivatives was synthesized and characterized (Scheme 1). The introduction of 2-aminophenol group into rhodamine not only enhanced the water solubility, more importantly, it also enabled the specific complexation of $\mathrm{Al}^{3+}$. The results demonstrated that the particular molecular structure gives rise to the high selectivity toward $\mathrm{Al}^{3+}$. Taking advantage of the rhodamine ring-opening reaction, fluorescence turn-on bioimaging of $\mathrm{Al}^{3+}$ in living cells confirms the great potential of chemosensor $\mathbf{P}$ in analyzing living biosystems.

\section{Results and discussion}

\section{1 $\mathrm{pH}$ effect on the fluorescent response of $\mathrm{P}$ and $\mathrm{P}-\mathrm{Al}^{3+}$}

Fluoroionophores are usually disturbed by proton in the detection of metal ions. Fig. 1 presents the fluorescence spectra of chemosensor $\mathbf{P}$ in ethanol-water solution $(9: 1, \mathrm{v}: \mathrm{v}, 20 \mathrm{mM}$ HEPES) at different $\mathrm{pH}$ values ranging from 4 to 10 . The fluorescence intensity of $\mathbf{P}$ is relatively stable when $\mathrm{pH}$ was higher than 5.0. However, the emission of $\mathrm{Al}^{3+}$ complex maintained fairly intense maximum emission between $\mathrm{pH} 4-7$. While at $\mathrm{pH}$ $>6$, the fluorescence intensity decrease may be due to the formation of $\mathrm{Al}(\mathrm{OH})_{3}$, thereby reducing the concentration of $\mathrm{Al}^{3+}$ complex. This result reveals that $\mathbf{P}$ exhibits satisfactory $\mathrm{Al}^{3+}$ sensing ability in the medium $\mathrm{pH}$ range. Thereby, the following experiments were carried out in solution at $\mathrm{pH}$ 5.8.

\subsection{Fluorescent properties of $\mathbf{P}$}

Usually, a highly selective chemosensor for $\mathrm{Al}^{3+}$ that gives a positive response rather than fluorescent quenching upon analyst binding is preferred to promote the sensitivity factor. To study the selectivity of $\mathbf{P}, 17$ metal ions with different valences

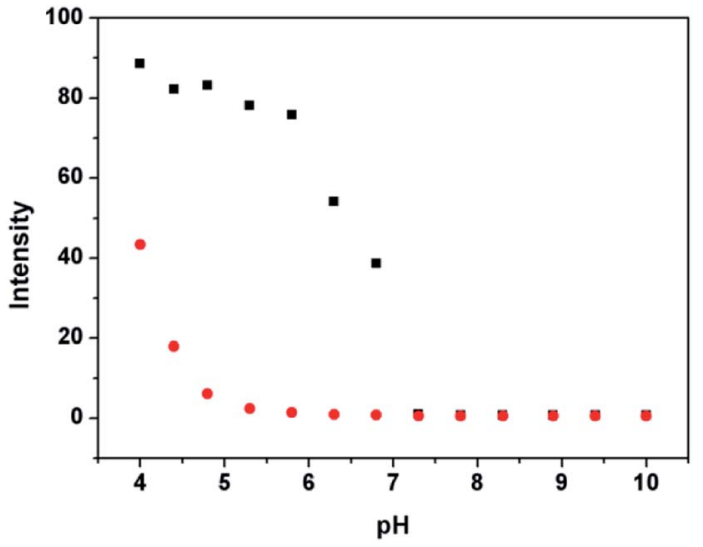

Fig. $1 \mathrm{pH}$-dependence of $\mathrm{P}(10 \mu \mathrm{M})(-)$ and $\mathrm{P}(10 \mu \mathrm{M})$ plus $4 \mu \mathrm{M} \mathrm{Al}^{3+}$ ( $)$ in HEPES buffers as a function of different $\mathrm{pH}$ values in ethanolwater solution ( $9: 1, v: v, 20 \mathrm{mM}$ HEPES).

were examined as the alternative of $\mathrm{Al}^{3+}$ for the incubation with P. As shown in Fig. 2a and S1a, (ESI $\dagger$ ), none of these ions can turn on the fluorescence of $\mathbf{P}$ under the same conditions, except $\mathrm{Cu}^{2+}$ and $\mathrm{Cr}^{3+}$ have a negligible interference. Under this condition, only $\mathrm{Al}^{3+}$ can induce distinct blue fluorescence variation at $578 \mathrm{~nm}$, the intensity was $250 \%$ of that induced by $\mathbf{P}(\Phi$ $=0.45$, see Cal. 1 in ESI $\dagger$ ), the emission band is reasonably
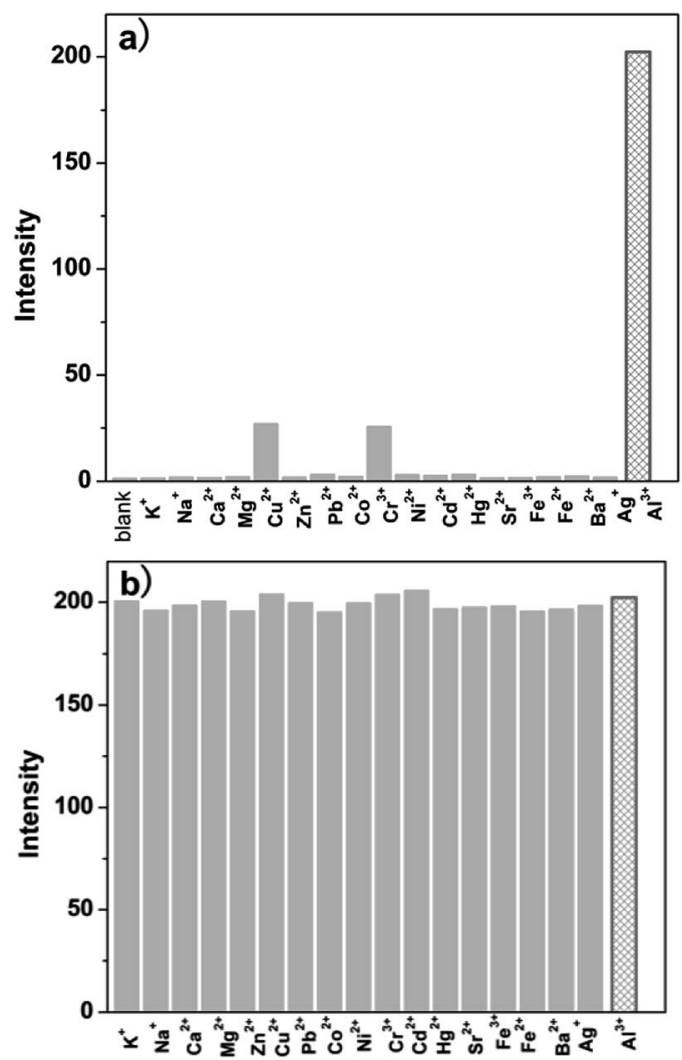

Fig. 2 (a) Fluorescence emission spectra of $P(10 \mu M)$ to different metal ions $(10 \mu \mathrm{M})$ in ethanol-water solution $(9: 1, \mathrm{v}: \mathrm{v}, \mathrm{pH} 5.8,20 \mathrm{mM}$ HEPES); (b) fluorescence response of $\mathrm{P}(10 \mu \mathrm{M})$ to $\mathrm{Al}^{3+}(10 \mu \mathrm{M})$ or to a mixture of the specified metal ions $(50 \mu \mathrm{M})$ with $\mathrm{Al}^{3+}(10 \mu \mathrm{M})$ in ethanol-water solution (9:1, v: v, pH 5.8, 20 mM HEPES). 
assigned to the delocalized xanthene tautomer of the rhodamine group. Meanwhile, compared with $\mathrm{Al}^{3+}$ that caused a remarkable increase in the fluorescence intensity at $578 \mathrm{~nm}$, the presence of other competing anions and ROS or RNS $\left(\mathrm{ClO}^{-}\right.$, $\mathrm{NO}_{3}{ }^{-}, \mathrm{CO}_{3}{ }^{2-}, \mathrm{Cl}^{-}, \mathrm{Ac}^{-}, \mathrm{ClO}_{4}{ }^{-}, \mathrm{Br}^{-}, \mathrm{I}^{-}, \mathrm{HPO}_{4}{ }^{2-}, \mathrm{H}_{2} \mathrm{O}_{2}, \mathrm{ONOO}^{-}$, . $\mathrm{OH}$ and $\cdot \mathrm{O}_{2}{ }^{-}$) had no significant fluorescence signal as shown in Fig. S1b (ESI $\dagger$ ).

Furthermore, to verify the ability of $\mathbf{P}$ to discriminate $\mathrm{Al}^{3+}$ in complex samples, $\mathrm{Al}^{3+}$ was analyzed in the mixture of the above mentioned 17 metal ions (as shown in Fig. 2b). Without any pretreatment, when selected metal ions $(50 \mu \mathrm{M})$ were added into ethanol-water solution (9:1, v : v, pH 5.8, $20 \mathrm{mM}$ HEPES) of $\mathbf{P}(10 \mu \mathrm{M})$ containing $\mathrm{Al}^{3+}$ ions $(10 \mu \mathrm{M})$, the mixed ion solution containing $\mathrm{Al}^{3+}$ releases fluorescence was similar to that with $\mathrm{Al}^{3+}$ ions alone. Also, it was investigated that the fluorescence response of $\mathbf{P}$ toward $\mathrm{Al}^{3+}$ in the presence of various coexistent anions and ROS or RNS such as $\mathrm{ClO}^{-}, \mathrm{NO}_{3}{ }^{-}, \mathrm{CO}_{3}{ }^{2-}$, $\mathrm{Cl}^{-}, \mathrm{Ac}^{-}, \mathrm{ClO}_{4}{ }^{-}, \mathrm{Br}^{-}, \mathrm{I}^{-}, \mathrm{HPO}_{4}{ }^{2-}, \mathrm{H}_{2} \mathrm{O}_{2}, \cdot \mathrm{OH}, \mathrm{ONOO}^{-}$and $\cdot \mathrm{O}_{2}{ }^{-}$. It is gratifying to note that all the tested competitive analytes have no interference (Fig. S2, ESI $\dagger$ ). For the $\mathrm{Al}^{3+}$ chemosensor $\mathbf{P}$, neither cross-sensitivity to the other metal ions nor to the commonly present anions, ROS and RNS was observed. These results clearly indicate the high selectivity of $\mathbf{P}$ for $\mathrm{Al}^{3+}$ over other species, which can facilitate the practical detection of $\mathrm{Al}^{3+}$ in complex biological samples.

The dependence of fluorescence emission of $\mathbf{P}$ on the concentration of $\mathrm{Al}^{3+}$ was investigated by incubation with $\mathrm{Al}^{3+}$ at concentrations ranging from 0.1 to $10 \mu \mathrm{M}$. As shown in Fig. 3, the fluorescence at $578 \mathrm{~nm}$ enhances gradually as the $\mathrm{Al}^{3+}$ concentration increases. The titration curve shows a steady and smooth increase until a plateau is reached. A linear dependence of fluorescence at $578 \mathrm{~nm}$ can be determined as a function of $\mathrm{Al}^{3+}$ concentration within $0.5-9 \mu \mathrm{M}$ (inset of Fig. 3), with the detection limit of $\mathbf{P}$ toward $\mathrm{Al}^{3+}$ to be $0.16 \mu \mathrm{M}$ based on $3 \times$ $\delta_{\text {blank } / k}$ (where $\delta_{\text {blank }}$ is the standard deviation of the blank solution and $k$ is the slope of the calibration plot), which is enough to satisfy the U.S. EPA and FDA guidelines of $7.41 \mu \mathrm{M}$ $\mathrm{Al}^{3+}$ for bottled drinking water. The results indicated that $\mathbf{P}$ could sensitively detect environmentally relevant levels of $\mathrm{Al}^{3+}$.

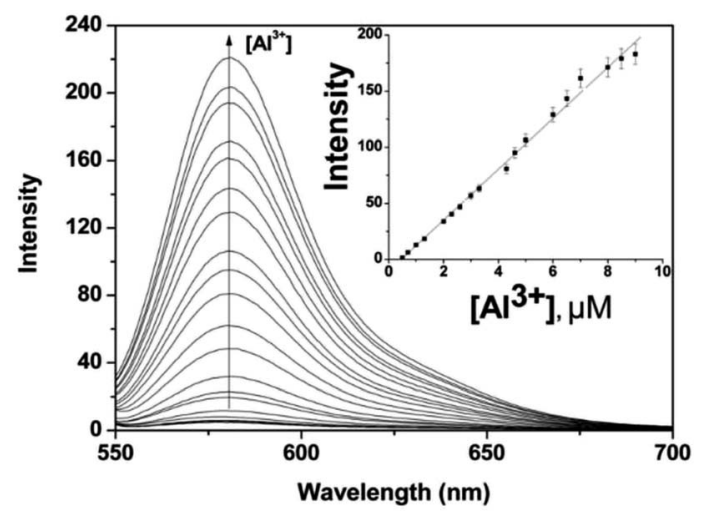

Fig. 3 Fluorescence spectra of $\mathrm{P}(10 \mu \mathrm{M})$ in the presence of different amounts of $\mathrm{Al}^{3+}(0-10 \mu \mathrm{M})$ in ethanol-water solution $(9: 1, \mathrm{v}: \mathrm{v}, \mathrm{pH}$ $5.8,20 \mathrm{mM}$ HEPES). Inset: linear fluorescence intensity at $578 \mathrm{~nm}$ of $P$ $(10 \mu \mathrm{M})$ upon addition of $\mathrm{Al}^{3+}(0.5-9 \mu \mathrm{M})$.

\subsection{Recognition mechanism of $\mathbf{P}$ to $\mathrm{Al}^{3+}$}

The Job's plot was carried out to prove the complex ratio of $\mathbf{P}$ with $\mathrm{Al}^{3+}$ (Fig. 4), total concentration of $\mathbf{P}$ and $\mathrm{Al}^{3+}$ was kept at a fixed $10 \mu \mathrm{M}$. The results showed that the maximum fluorescence emission intensity of $\mathbf{P}-\mathrm{Al}^{3+}$ complex appeared at 0.5 , which indicated that $\mathbf{P}$ and $\mathrm{Al}^{3+}$ formed a $1: 1$ complex. If $\mathbf{P}$ binds with $\mathrm{Al}^{3+}$ to form a complex with a complexing ratio of $1: 1$, one can describe the equilibrium as follows (eqn (1)):

$$
\mathrm{P}+\mathrm{Al}^{3+} \stackrel{k}{\longrightarrow} \mathrm{P} \cdot \mathrm{Al}^{3+}
$$

The binding constant for the formation of $\mathbf{P}-\mathrm{Al}^{3+}$ complex was evaluated using the Benesi-Hildebrand (B-H) plot (eqn (2), with details in Cal. 2, ESI $\dagger)^{16}$

$$
\frac{1}{F-F_{0}}=\frac{1}{k\left(F_{\max }-F_{0}\right)\left[\mathrm{Al}^{3+}\right]_{0}}+\frac{1}{F_{\max }-F_{0}}
$$

$F_{0}$ is the fluorescence intensity of $\mathbf{P}$ without $\mathrm{Al}^{3+}, F$ is the fluorescence intensity of $\mathbf{P}$ obtained with $\mathrm{Al}^{3+}, F_{\max }$ is the fluorescence intensity of $\mathbf{P}$ in the presence of excess amount of $\mathrm{Al}^{3+}$, $k$ is the binding constant $\left(\mathbf{M}^{-1}\right)$ and was determined from the slope of the linear plot. The Benesi-Hildebrand analysis of the emission data gives a 1:1 stoichiometry for the $\mathbf{P}-\mathrm{Al}^{3+}$ complexation species, with an association constant $(k)$ being calculated as $6.9 \times 10^{4} \mathrm{M}^{-1}$ (Fig. S3, ESI $\dagger$ ), corresponding to a stronger binding capability toward $\mathrm{Al}^{3+}$ in comparison with a pyrazoline derivative based chemosensor for $\mathrm{Al}^{3+}$ (with a $k$ value of $\left.2.13 \times 10^{3} \mathrm{M}^{-1}\right),{ }^{17}$ or a naphthadehyde derivative based chemosensor for $\mathrm{Al}^{3+}$ (with a $k$ value of $2.5 \times 10^{3} \mathrm{M}^{-1}$ ). ${ }^{18}$

To better understanding their binding behavior, ESI-MS of $\mathbf{P}$ $\mathrm{Al}^{3+}$ characterization was performed. $m / z$ : 649.21 corresponding to $\left[\mathbf{P}+\mathrm{Al}^{3+}+\mathrm{Cl}^{-}-\mathrm{H}^{+}\right]^{+}$confirmed the formation of the $1: 1$ complex (Fig. S4, ESI $\dagger$ ). To further strengthen the explanation, the IR spectra of $\mathbf{P}$ and $\mathbf{P}-\mathrm{Al}^{3+}$ were given in Fig. S5. $\dagger$ The carbonyl stretching frequency of spirolactam ring in free chemosensor $\mathbf{P}$ and the $\mathbf{P}-\mathrm{Al}^{3+}$ complex are $1732.8 \mathrm{~cm}^{-1}$ and $1700.8 \mathrm{~cm}^{-1}$, respectively. This shifting $\left(32.0 \mathrm{~cm}^{-1}\right)$ indicates the spirolactam ring opening phenomena where carbonyl

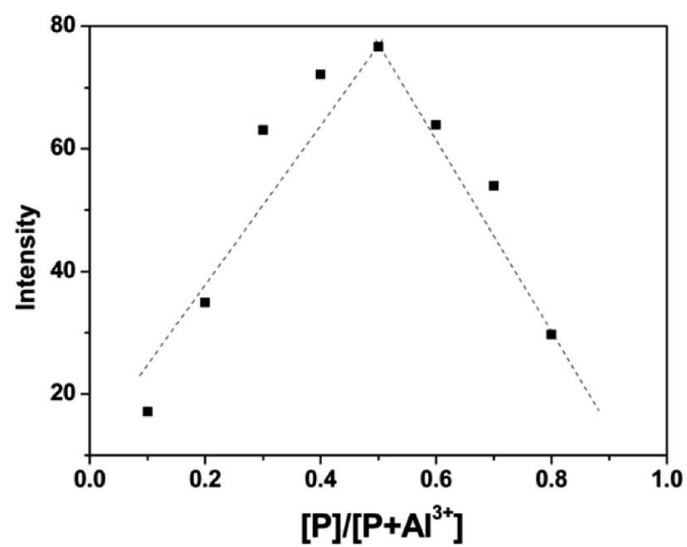

Fig. 4 Job-plot of $\mathrm{P}$ with $\mathrm{Al}^{3+}$. Total concentration of $\mathrm{P}$ and $\mathrm{Al}^{3+}$ was kept as $10 \mu \mathrm{M}$. 


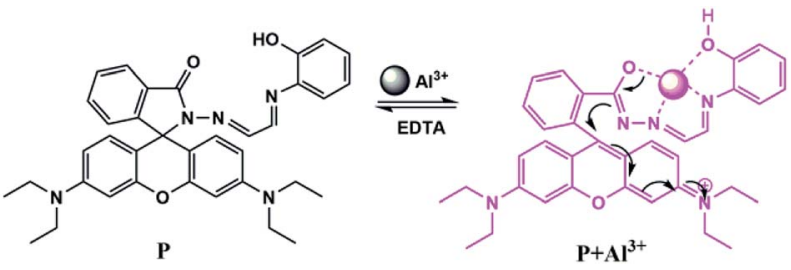

Scheme 2 Proposed binding mode between $\mathrm{P}$ and $\mathrm{Al}^{3+}$

oxygen make a bond towards $\mathrm{Al}^{3+}$ ion as reported earlier. ${ }^{19}$ Meanwhile, ${ }^{1} \mathrm{H}$ NMR titrations were performed to strengthen the proposed reaction mechanism and plausible binding mode as shown in Fig. S6a (ESI $\dagger$ ). Peak of $-\mathrm{OH}$ proton of $\mathbf{P}$ at $9.27 \mathrm{ppm}$ disappears on addition of 1.0 equiv. of $\mathrm{Al}^{3+}$, supporting the deprotonation of $\mathbf{P}$, and a new peak at $10.99 \mathrm{ppm}$ indicates the spiro-cycle opening and formation of a new -OH group. The above results indicate that a plausible binding mode of $\mathbf{P}-\mathrm{Al}^{3+}$ includes a coordinated ' $\mathrm{N}$ ', spirocarbonyl ' $\mathrm{O}$ ' and - $\mathrm{OH}$. Additionally, the spirolactam ring opening mechanism was also established from the disappearance of the tertiary carbon signal appeared at $\delta=65.18 \mathrm{ppm}$ and appearance of a new signal at $\delta=137.09$ ppm upon addition 1.0 equiv. of $\mathrm{Al}^{3+}$ (Fig. S6b), ESI. $\dagger$ This is attributed to the conversion of $\mathrm{sp}^{3}$ spiro carbon of rhodamine to $\mathrm{sp}^{2}$ carbon upon binding with $\mathrm{Al}^{3+}$ ion..$^{20}$

According to the experimental results, the reaction mechanism was proposed as shown in Scheme 2. Namely, without $\mathrm{Al}^{3+}, \mathbf{P}$ existed in a non-fluorescence spirocyclic form. Addition of $\mathrm{Al}^{3+}$ led to the formation of five-membered ring by coordination with the ligand groups (oxygen and nitrogen atoms on the phenolic hydroxyl group and rhodamine unit, respectively), resulting in spiro-cycle opening along with an appearance of pink fluorescence. It is believed that this process is reversible, which has been proved by the test using EDTA-Al ${ }^{3+}$ (Fig. S7, ESI†). Thus, a reversible "off-on" based fluorescent chemosensor for $\mathrm{Al}^{3+}$ was constructed.

\subsection{Application study of $\mathbf{P}$}

The good stability of the fluorescence switched on by $\mathrm{Al}^{3+}$ in the $\mathrm{pH}$ range of 4.0-7.0 provides the chemosensor with good suitability for the application in bioimaging of living cells. Confocal microscopy experiments were carried out to demonstrate the practical applicability of $\mathbf{P}$, and the fluorescence images of HepG2 cells were recorded before and after the addition of $\mathrm{Al}^{3+}$ (Fig. 5). When the cells incubated with $\mathbf{P}$ for $30 \mathrm{~min}$ at $37^{\circ} \mathrm{C}$, no background fluorescence was observed from HepG2 cells themselves, suggesting that autofluorescence from the cells can be avoided and no fluorescence signal was detected in cells only treated with $\mathbf{P}$ (Fig. 5a). Under this condition, for the P-loaded HepG2 cells, a strong fluorescence was detected after incubation with $\mathrm{Al}^{3+}$ (Fig. 5c), demonstrating the membrane penetrability of $\mathbf{P}$ and the complexation with $\mathrm{Al}^{3+}$ inside the cells, clearly demonstrating that $\mathrm{Al}^{3+}$ and its interaction with $\mathbf{P}$ are essential for the fluorescence turn-on. The bright field images of Fig. 5a and $\mathrm{c}$ were shown as Fig. $5 \mathrm{~b}$ and d, respectively, whose shapes of cells indicated that $\mathbf{P}$ has low toxicity, revealing good biocompatibility of $\mathbf{P}$ for bioanalysis.

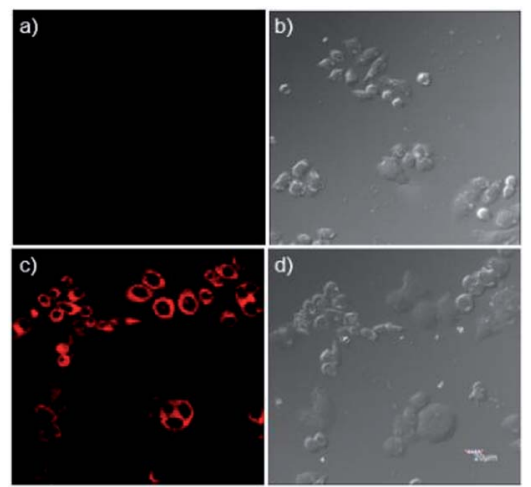

Fig. 5 Confocal fluorescence and brightfield images of HepG2 cells. (a) Cells stained with $20 \mu \mathrm{M}$ P for 30 min at $37^{\circ} \mathrm{C}$; (b) bright field image of cells shown in panel (a); (c) cells supplemented with $1 \mu \mathrm{M} \mathrm{Al}^{3+}$ in the growth media for $1 \mathrm{~h}$ at $37^{\circ} \mathrm{C}$, and then incubated with $20 \mu \mathrm{M}$ P for $30 \mathrm{~min}$ at $37^{\circ} \mathrm{C}$; (d) brightfield image of cells shown in panel (c). $\left(\lambda_{\text {ex }}=\right.$ $559 \mathrm{~nm})$.

As a control, the cells not treated with $\mathrm{Al}^{3+}$ were also imaged, which showed faint fluorescence (Fig. 6a), but with the increase of the concentration of $\mathrm{Al}^{3+}(0.1,0.5,1.0,2.0 \mu \mathrm{M})$ in living cells, the intensity of fluorescence was enhanced regularly (Fig. 6b-e). The reversibility of $\mathbf{P}$ with $\mathrm{Al}^{3+}$ in living cells was also conducted using $N, N, N^{\prime}, N^{\prime}$-Tetrakis (2-pyridylmethyl)ethylenediamine (TPEN) as chelating agent, and results show that the coordination of $\mathbf{P}$ with $\mathrm{Al}^{3+}$ was reversible (Fig. 6f). The cell body regions in the visual field (Fig. 6b-e) were selected as the regions of interest (ROI), and the average fluorescence intensity was
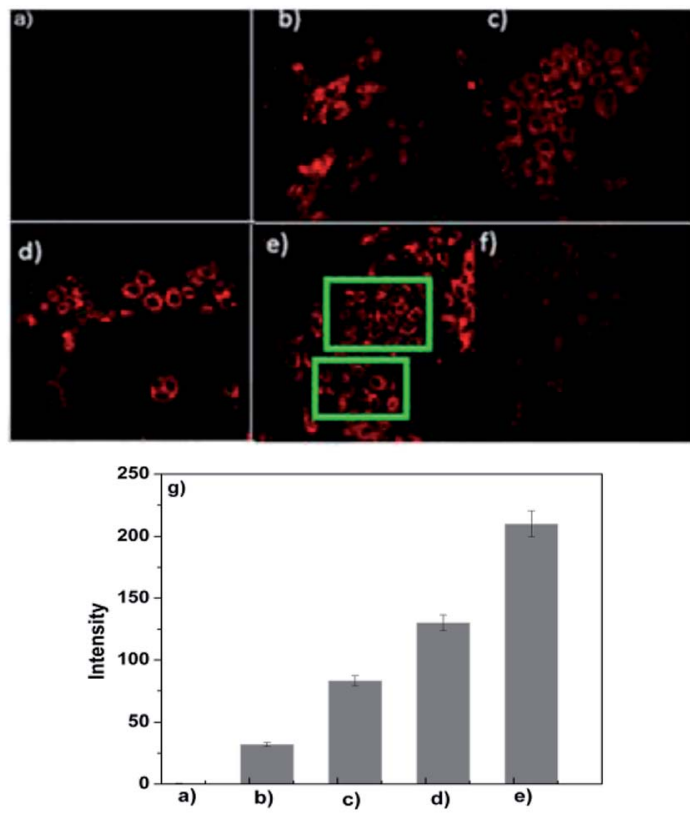

Fig. 6 Confocal fluorescence images of HepG2 cells. (a-e) Cells supplemented with $0,0.1,0.5,1.0$ and $2.0 \mu \mathrm{M} \mathrm{Al}^{3+}$ in the growth media for $1 \mathrm{~h}$ at $37^{\circ} \mathrm{C}$, and then incubated with $20 \mu \mathrm{M} \mathrm{P}$ for 30 min at $37^{\circ} \mathrm{C}$, respectively; (f) cells supplemented with $2.0 \mu \mathrm{M} \mathrm{Al}^{3+}$ in the growth media for $1 \mathrm{~h}$ at $37^{\circ} \mathrm{C}$, and then incubated with $20 \mu \mathrm{M} \mathrm{P}$ for $30 \mathrm{~min}$ at $37^{\circ} \mathrm{C}$, and then treated with TPEN; $(\mathrm{g})$ fluorescence enhancement of $\mathrm{P}$ with the increasing of $\mathrm{Al}^{3+}$ concentration (a-e: $0,0.1,0.5,1.0$ and 2.0 $\left.\mu \mathrm{MAl}^{3+}\right)$. 
determined via confocal laser scanning microscopy with various $\mathrm{Al}^{3+}$ concentrations (Fig. $6 \mathrm{~g}$ ). The results suggested that $\mathbf{P}$ had good membrane permeability, and these data also established that $\mathbf{P}$ could respond to intracellular $\mathrm{Al}^{3+}$ level changes within living cells.

We also applied $\mathbf{P}$ to the subcellular locations of $\mathrm{Al}^{3+}$ in the HepG2 cells using confocal fluorescence microscopy. The cells, with the same condition used in Fig. 6d, were co-stained with $\mathbf{P}$ $(10 \mu \mathrm{M})$ and Hoechst $33342\left(1 \mu \mathrm{g} \mathrm{mL}^{-1}\right)$ for $30 \mathrm{~min}$. Fig. S8 (ESI $\dagger$ ) further reveals that $\mathbf{P}$ primarily locates in the cytoplasm of these living HepG2 cells.

\subsection{Methods comparison}

Many fluorescent chemosensors have been reported for the determination of $\mathrm{Al}^{3+}$. The performance comparison of $\mathbf{P}$ and others reported chemosensors are listed in Table S1 (ESI $\dagger$ ). It is can be seen from Table $\mathrm{S} 1 \dagger$ that most fluorescent chemosensors present good selectivity and reversibility for $\mathrm{Al}^{3+},{ }^{17,18,21-24,26}$ high fluorescence quantum yield, ${ }^{21-23,26}$ even down to $0.001 \mu \mathrm{M}$ LOD ${ }^{18}$ and satisfactory qualitative analysis of cell imaging, ${ }^{17,22,26}$ high binding constants at the level of $10^{4} \mathrm{M}^{-1,21-23,26}$ but some of them have more or less disadvantages, such as big background fluorescence, ${ }^{21,23,25}$ and unsuitable for cell imaging, ${ }^{18,21,23-25}$ irreversibility, ${ }^{25}$ pure organic solvent. ${ }^{18,21,25}$ Our newly developed chemosensor $\mathbf{P}$ based on rhodamine spirolactame derivative presents a number of attractive analytical features such as excellent detection limit, high association constant, good selectivity, high fluorescence quantum yield, good reproducibility, and wide qualitative and quantitative analysis of ultratrace level $\mathrm{Al}^{3+}$ in living cells.

\section{Experimental}

All reagents and solvents are of analytical grade and used without further purification. The metal ions salts employed were $\mathrm{NaCl}, \mathrm{KCl}, \mathrm{CaCl}_{2} \cdot 2 \mathrm{H}_{2} \mathrm{O}, \mathrm{MgCl}_{2} \cdot 6 \mathrm{H}_{2} \mathrm{O}, \mathrm{Zn}\left(\mathrm{NO}_{3}\right)_{2} \cdot 6 \mathrm{H}_{2} \mathrm{O}$, $\mathrm{PbCl}_{2}, \mathrm{FeCl}_{3} \cdot 6 \mathrm{H}_{2} \mathrm{O}, \mathrm{CrCl}_{3} \cdot 6 \mathrm{H}_{2} \mathrm{O}, \mathrm{CoCl}_{2} \cdot 6 \mathrm{H}_{2} \mathrm{O}, \mathrm{NiCl}_{2} \cdot 6 \mathrm{H}_{2} \mathrm{O}$, $\mathrm{CuCl}_{2} \cdot 2 \mathrm{H}_{2} \mathrm{O}, \mathrm{CdCl}_{2}, \mathrm{Hg}\left(\mathrm{NO}_{3}\right)_{2}, \mathrm{AgNO}_{3}$ and $\mathrm{AlCl}_{3} \cdot 6 \mathrm{H}_{2} \mathrm{O}$, respectively.

Fluorescence emission spectra were conducted on a Hitachi 4600 spectrofluorometer. UV-Vis spectra were obtained on a Hitachi U-2910 spectrophotometer. Nuclear magnetic resonance (NMR) spectra were measured with a Brucker AV 400 instrument and chemical shift were given in ppm from tetramethylsilane (TMS). Mass (MS) spectra were recorded on a Thermo TSQ Quantum Access Agilent 1100.

\subsection{Synthesis of $\mathbf{P}$}

2-Aminophenol (0.120 g, $1.1 \mathrm{mmol}$ ) and RhB2 (ref. 27) (0.496 g, $1.0 \mathrm{mmol})$ were mixed in ethanol $(40 \mathrm{~mL})$. The reaction mixture was stirred at $80{ }^{\circ} \mathrm{C}$ for $4 \mathrm{~h}$ and then cooled to room temperature, the solution was removed under reduced pressure. The precipitate so obtained was filtered and purified with silica gel column chromatography (petroleum ether/acetic ether $=5: 1$, $\mathrm{v}: \mathrm{v}$ ) to afford $\mathbf{P}$ as yellow solid. Yields: $83.4 \%$. MS (ES+) $m / z$ : $588.30[\mathrm{M}+\mathrm{H}]^{+}$. IR $\left(\mathrm{KBr}, \mathrm{cm}^{-1}\right): \nu=3404,2968,1732,1700$,
1634, 1615, 1515, 1466, 1308, 1263, 1219, 1118, 1078, 820, 753; ${ }^{1} \mathrm{H}$ NMR ([ $\left.\left.d_{6}\right] \mathrm{DMSO}\right): \delta=9.40(\mathrm{~s}, 1 \mathrm{H}), 9.26(\mathrm{~d}, 1 \mathrm{H}, J=7.48), 8.17$ $(\mathrm{d}, 1 \mathrm{H}, J=8.24), 8.00(\mathrm{~d}, 1 \mathrm{H}, J=7.56), 7.94(\mathrm{~d}, 1 \mathrm{H}, J=7.48), 7.67$ (t, 1H, $J=7.48), 7.61(\mathrm{~d}, 1 \mathrm{H}, J=7.00), 7.45(\mathrm{~d}, 1 \mathrm{H}, J=7.48), 7.08$ $(\mathrm{t}, 1 \mathrm{H}, J=8.98), 7.02(\mathrm{~d}, 1 \mathrm{H}, J=7.40), 6.84(\mathrm{~d}, 1 \mathrm{H}, J=8.08), 6.73$ $(\mathrm{t}, 1 \mathrm{H}, J=7.62), 6.46(\mathrm{~d}, 1 \mathrm{H}, J=8.16), 6.44(\mathrm{~s}, 1 \mathrm{H}), 6.40(\mathrm{t}, 1 \mathrm{H}, J=$ 10.52), 6.37 (d, $1 \mathrm{H}, J=6.40), 6.34(\mathrm{~d}, 1 \mathrm{H}, J=6.04), 3.32(\mathrm{~m}, 8 \mathrm{H}, J$ $=8.55), 1.08(\mathrm{t}, 12 \mathrm{H}, J=6.90) ;{ }^{13} \mathrm{C} \mathrm{NMR}\left(\left[d_{6}\right] \mathrm{DMSO}\right): \delta=164.53$, 157.96, 152.34, 152.13, 151.17, 148.64, 136.75, 128.40, 127.34, $123.69,123.38,120.74,119.42$, 116.39, 108.22, 104.39, 97.52, 65.18, 43.63, 12.40. (Fig. S9-11†) anal. calcd (\%) for $\mathrm{C}_{36} \mathrm{H}_{37} \mathrm{~N}_{5} \mathrm{O}_{3}$ (MW 539.68): C 73.57; H 6.35; N 11.92. Found C 72.89; H 6.38; N 11.95 .

\subsection{General spectroscopic methods}

Metal ions and $\mathbf{P}$ were dissolved in deionized water and DMSO to obtain $1.0 \mathrm{mM}$ stock solutions, respectively. Before spectroscopic measurements, the solution was freshly prepared by diluting the high concentration stock solution to the corresponding solution. For all measurements, excitation and emission slit widths were $5 / 10 \mathrm{~nm}$, excitation wavelength was $540 \mathrm{~nm}$.

\subsection{Cell culture}

HepG2 cells were purchased from the Committee on Type Culture Collection of Chinese Academy of Sciences (Shanghai, China). HepG2 cells were incubated in DMEM (Dulbecco's Modified Eagle Medium) supplemented with 10\% fetal bovine serum (FBS).

\section{Conclusions}

A novel $\mathrm{Al}^{3+}$-selective rhodamine $\mathrm{B}$ fluorescent chemosensor was synthesized and characterized. $\mathrm{Al}^{3+}$ could induce spirolactam ring opening of the rhodamine unit and achieved "offon" effect. In addition, the proposed $\mathbf{P}$ has been successfully used to detect $\mathrm{Al}^{3+}$ in living cells quantitatively and qualitatively.

\section{Conflicts of interest}

There are no conflicts to declare.

\section{Acknowledgements}

This work was financially supported by the National Natural Science Foundation of China (No. 81560347, 81660356, 81760387), Key Research and Development Projects of Hainan Province (No. ZDYF2017103).

\section{Notes and references}

1 (a) Z. C. Liu, Z. Y. Yang, Y. X. Li, T. R. Li, B. D. Wang, Y. Li and X. L. Jin, Inorg. Chim. Acta, 2013, 395, 77; (b) J. Lee, H. Kim, S. Kim, J. Y. Noh, E. J. Song, C. Kim and J. Kim, Dyes Pigm., 2013, 96, 590; (c) J. C. Qin, L. Fan, T. R. Li and Z. Y. Yang, Synth. Met., 2015, 199, 179. 
2 (a) J. Barceló and C. Poschenrieder, Environ. Exp. Bot., 2002, 48, 75; (b) Z. Krejpcio and R. W. Wójciak, Pol. J. Environ. Stud., 2002, 11, 251.

3 (a) S. W. King, J. Savory and M. R. Willis, Crit. Rev. Clin. Lab. Sci., 1981, 13, 1; (b) I. S. Parkinson, M. K. Ward and D. N. Kerr, J. Clin. Pathol., 1981, 34, 1285; (c) A. M. Pierdes, Int. J. Artif. Organs, 1978, 1, 206.

4 (a) S. Z. Pu, Q. Sun, C. B. Fan, R. J. Wang and G. Liu, J. Mater. Chem., 2016, 4, 3075; (b) Y. L. Fu, Y. Y. Tu, C. B. Fan, C. H. Zheng, G. Liu and S. Z. Pu, New J. Chem., 2016, 40, 8579; (c) S. Z. Pu, C. C. Zhang, C. B. Fan and G. Liu, Dyes Pigm., 2016, 129, 24; (d) Y. L. Fu, C. B. Fan, G. Liu, S. Q. Cui and S. Z. Pu, Dyes Pigm., 2016, 126, 121; (e) H. C. Ding, B. Q. Li, S. Z. Pu, G. Liu, D. C. Jia and Z. Yu, Sens. Actuators, B, 2017, 247, 26; (f) Y. L. Fu, C. B. Fan, G. Liu and S. Z. Pu, Sens. Actuators, B, 2017, 239, 295.

5 (a) X. Sun, Y. W. Wang and Y. Peng, Org. Lett., 2012, 14, 3420; (b) K. K. Upadhyay and A. Kumar, Org. Biomol. Chem., 2010, 8, 4892 .

6 (a) O. Alici and S. Erdemir, Sens. Actuators, B, 2015, 208, 159; (b) J. Kumar, M. J. Sarma, P. Phukan and D. K. Das, Dalton Trans., 2015, 44, 4576; (c) C. A. Huerta-Aguilar, P. Raj, P. Thangarasu and N. Singh, RSC Adv., 2016, 6, 37944; (d) S. Mukherjee, P. Mal and H. Stoeckli-Evans, J. Lumin., 2016, 172, 124-130.

7 (a) Y. Li, C. Liao, S. Huang, H. Xu, B. Zheng, J. Du and D. Xiao, $R S C A d v ., 2016,6,25420$; (b) S. M. Hossain, K. Singh, A. Lakma, R. N. Pradhan and A. K. Singh, Sens. Actuators, B, 2017, 239, 1109; (c) B. K. Datta, D. Thiyagarajan, A. Ramesh and G. Das, Dalton Trans., 2015, 44, 13093; (d) L. Kang, Z. Y. Xing, X. Y. Ma, Y. T. Liu and Y. Zhang, Spectrochim. Acta, Part A, 2016, 167, 59.

8 (a) I. H. Hwang, Y. W. Choi, K. B. Kim, G. J. Park, J. J. Lee, L. Nguyen, I. Noh and C. Kim, New J. Chem., 2016, 40, 171; (b) J. Ma, W. Shi, L. Feng, Y. Chen, K. Fan, Y. Hao, Y. Hui and Z. Xie, $R S C A d v$., 2016, 6, 28034; (c) C. Liang, W. Bu, C. Li, G. Men, M. Deng, Y. J. Yao, H. Sun and S. Jiang, Dalton Trans., 2015, 44, 11352; (d) R. Alam, T. Mistri, R. Bhowmick, A. Katarkar, K. Chaudhuri and M. Ali, RSC $A d v .$, 2016, 6, 1268; (e) V. K. Gupta, S. K. Shoora, L. K. Kumawat and A. K. Jain, Sens. Actuators, B, 2015, 209, 15.

9 (a) J. C. Qin, J. Yan, B. D. Wang and Z. Y. Yang, Tetrahedron Lett., 2016, 57, 1935; (b) S. Paul, S. Goswami and A. Manna, Dalton Trans., 2015, 44, 11805.

10 (a) Y. M. Xue, R. J. Wang, C. H. Zheng, G. Liu and S. Z. Pu, Tetrahedron Lett., 2016, 57, 1877; (b) S. Goswami, K. Aich, S. Das, A. K. Das, D. Sarkar, S. Panja, T. K. Mondal and S. Mukhopadhyay, Chem. Commun., 2013, 49, 10739.

11 (a) E. T. Feng, C. B. Fan, N. S. Wang, G. Liu and S. Z. Pu, Dyes Pigm., 2018, 151, 22; (b) E. Oliveira, H. M. Santos, J. L. Capelo and C. Lodeiro, Inorg. Chim. Acta, 2012, 381, 203; (c) R. Azadbakht and J. Khanabadi, Inorg. Chem. Commun., 2013, 30, 21.

12 (a) P. Torawane, K. Tayade, S. Bothra, S. K. Sahoo, N. Singh and A. Borse, Sens. Actuators, B, 2016, 222, 562; (b) C. R. Li, J. C. Qin, G. Q. Wang, B. D. Wang, A. K. Fu and Z. Y. Yang,
Inorg. Chim. Acta, 2015, 430, 91; (c) L. K. Kumawat, N. Mergu, M. Asif and V. K. Gupta, Sens. Actuators, B, 2016, 231, 847; (d) C. R. Li, Z. C. Liao, J. C. Qin, B. D. Wang and Z. Y. Yang, J. Lumin., 2015, 168, 330.

13 (a) K. Tiensomjitr, R. Noorat, K. Wechakorn, S. Prabpai, K. Suksen, P. Kanjanasirirat, Y. Pewkliang, S. Borwornpinyo and P. Kongsaeree, Spectrochim. Acta, Part A, 2017, 185, 228; (b) M. J. Liu, J. Yuan, J. Tao, Y. Q. Zhang, C. M. Liu and H. Z. Kou, Inorg. Chem., 2018, 57, 4061; (c) Z. Q. Mao, H. Jiang, X. J. Song, W. Hu and Z. H. Liu, Anal. Chem., 2017, 89, 9620; (d) R. J. Iwatate, M. Kamiya, K. Umezawa, H. Kashima, M. Nakadate, R. Kojima and Y. Urano, Bioconjugate Chem., 2018, 29, 241; (e) A. Rai, A. K. Singh, K. Tripathi, A. K. Sonkar and B. S. Chauhan, Sens. Actuators, B, 2018, 266, 95; (f) J. Tang, S. G. Ma, D. Zhang, Y. Q. Liu, Y. F. Zhao and Y. Ye, Sens. Actuators, B, 2016, 236, 109; (g) Z. Q. Mao, H. Jiang, X. J. Song, W. Hu and Z. H. Liu, Anal. Chem., 2017, 89, 9620; $(h)$ S. Li, D. Zhang, X. Y. Xie, S. G. Ma, Y. Liu, Z. H. Xu, Y. F. Gao and Y. Ye, Sens. Actuators, B, 2016, 224, 661; (i) F. Yan, R. Zhang, Y. Huang, D. Kong and Q. Ye, RSC Adv., 2016, 6, 50732; (j) J. Y. Cheng, E. B. Yang, P. G. Ding, J. Tang, D. Zhang, Y. F. Zhao and Y. Ye, Sens. Actuators, B, 2015, 221, 688.

14 (a) S. Paul, S. Goswami and A. Manna, Dalton Trans., 2015, 44, 11805; (b) Y. Kim, G. Jang and T. S. Lee, ACS Appl. Mater. Interfaces, 2015, 7, 15649; (c) M. Yu, R. Yuan, C. Shi, W. Zhou, L. Wei and Z. Li, Dyes Pigm., 2013, 99, 887; (d) A. Rai, N. Kumari, A. K. Srivastava, S. K. Singh, S. Srikrishna and L. Mishra, J. Photochem. Photobiol., A, 2016, 319, 78; (e) H. S. Kim, S. Angupillai and Y. A. Son, Sens. Actuators, B, 2016, 222, 447; (f) S. Chemate and N. Sekar, Sens. Actuators, B, 2015, 220, 1196; $(g)$ P. G. Ding, J. H. Wang, J. Y. Cheng, Y. F. Zhao and Y. Ye, New J. Chem., 2015, 39, 342; (h) S. Dey, S. Sarkar, D. Maity and P. Roy, Sens. Actuators, B, 2017, 246, 518.

15 (a) D. Maity and T. Govindaraju, Inorg. Chem., 2010, 49, 7229; (b) D. Maity and T. Govindaraju, Chem. Commun., 2010, 46, 4499.

16 (a) M. I. Rodriguez-Caceres, R. A. Agbaria and I. M. Warner, J. Fluoresc., 2005, 15, 185; (b) H. A. Benesi and J. H. Hildebrand, J. Am. Chem. Soc., 1949, 71, 2703; (c) F. Han, Y. Bao, Z. Yang, T. M. Fyles, J. Zhao, X. Peng, J. Fan, Y. Wu and S. Sun, Chem.-Eur. J., 2007, 13, 2880.

17 R. Manjunath and K. Palaninathan, New J. Chem., 2018, 42, 10891.

18 C. Y. Sun, X. Miao, L. J. Zhang, W. J. Li and Z. D. Chang, Inorg. Chim. Acta, 2018, 478, 112.

19 P. Mahato, S. Saha, E. Suresh, R. Di Liddo, P. P. Parnigotto, M. T. Conconi, M. K. Kesharwani, B. Ganguly and A. Das, Inorg. Chem., 2012, 51, 1769.

20 B. Sen, S. Pal, S. Lohar, M. Mukherjee, S. K. Mandal, A. R. Khuda-Bukhshb and P. Chattopadhyay, RSC Adv., 2014, 4, 21471.

21 D. Maity and T. Govindaraju, Chem. Commun., 2010, 46, 4499. 
22 A. Rai, A. K. Singh, K. Tripathi, A. K. Sonkar, B. S. Chauhan, S. Srikrishna, T. D. James and L. Mishra, Sens. Actuators, B, 2018, 266, 95.

23 K. Shen, S. Mao, X. Shi, F. Wang, Y. L. Xu, S. O. Aderinto and H. L. Wu, Luminescence, 2017, 33, 54.

24 S. Mabhai, M. Dolai, S. Dey, A. Dhara, B. Das and A. Jana, New J. Chem., 2018, 42, 10191.
25 G. Kumar, K. Paul and V. Luxami, Sens. Actuators, B, 2018, 263, 585.

26 A. Rai, N. Kumari, A. K. Srivastava, S. K. Singh, S. Srikrishna and L. Mishra, J. Photochem. Photobiol., A, 2016, 319, 78.

27 X. F. Yang, X. Q. Guo and Y. B. Zhao, Talanta, 2002, 57, 883. 